\title{
KEEFEKTIFAN PENERAPAN MODEL PEMBELAJARAN BERBASIS PROYEK DALAM PENCAPAIAN ASPEK KEMAMPUAN REPRESENTASI DAN KOMUNIKASI MATEMATIS SISWA KELAS VI SD NEGERI 118296 BERINGIN JAYA PINANG DAMAI
}

\author{
Nurlina Ariani Hrp ${ }^{1}$, Indah Fitria Rahma ${ }^{2}$ \\ FKIP Universitas Labuhanbatu, Rantauprapat, Sumatera Utara, Indonesia ${ }^{1,2}$ \\ e-mail: nurlinaariani561@gmail.com
}

\begin{abstract}
ABSTRAK
Tujuan penelitian ini adalah untuk melihat tingkat efektifitas penerapan model pembelajaran berbasis proyek dalam pencapaian aspek kemampuan representasi dan komunikasi matematis siswa pada kelas VI di SD Negeri 118296 Beringin Jaya Pinang Damai. Penelitian ini berdasarkan dengan latarbelakang proses pembelajaran di SD Negeri 118296 Beringin Jaya tersebut yang ditemukan bahwa guru kurang memperhatikan kemampuan representasi dan komunikasi matematis siswa dalam pembelajaran dengan tidak menggunakan model-model pembelajaran yang inovatif dan terintegrasi dengan kemampuan-kemampuan siswa dalam matematika. Jenis penelitian ini adalah penelitian eksperimen semu dengan metode penelitian kuantitatif. Penggunaan instrumen tes disusun berdasarkan indikator kemampuan representasi dan kemampuan komunikasi matematis. Dengan syarat validitas isi, serta koefisien reliabilitas tercapai. Hasil data dianalisis dengan analisis uji Anava dua jalur dengan sebelumnya dilakukan uji normalitas dan homogenitas dengan taraf signifikan 5\%. Hasil analisis data diperoleh hasil penelitian: (1) model pembelajaran berbasis proyek lebih efektif dalam meningkatkan kemampuan representasi matematis siswa daripada siswa yang memperoleh pembelajaran biasa, (2) model pembelajaran berbasis proyek lebih efektif dalam meningkatkan kemampuan komunikasi matematis siswa daripada siswa yang memperoleh pembelajaran biasa, dan (3) interaksi antara model pembelajaran berbasis proyek dan kemampuan awal matematik terhadap kemampuan representasi dan komunikasi matematis siswa. Hasil penelitian menunjukkan model pembelajaran berbasis proyek efektif digunakan dalam pembelajaran disekolah untuk mencapai target kompetensi dan pembelajaran inovatif.
\end{abstract}

\section{Kata Kunci:}

Komunikasi; Matematis; Pembelajaran; Proyek; Representasi.

\begin{abstract}
The purpose of this research was to know the level of effectiveness of the application of projectbased learning models in achieving aspects of mathematical representation and communication skills of students in grade VI at SD Negeri 118296 Beringin Jaya Pinang Damai. This research is based on the background of the learning process at SD Negeri 118296 Beringin Jaya, it was found that the teacher did not pay attention to the students 'mathematical representation and communication skills in learning by not using innovative learning models that were integrated with the students' abilities in mathematics. This type of research is quasi-experimental research with quantitative research methods. The use of test instruments is arranged based on indicators of representation ability and mathematical communication skills. With the terms of content validity, and the reliability coefficient is achieved. The results of the data were analyzed using two-way ANOVA test analysis with previously carried out the normality and homogeneity tests with a significant level of 5\%. The results of data analysis obtained the results of the study: (1) the project-based learning model was more effective in increasing the mathematical representation ability of students than students who received ordinary learning, (2) the project-based learning model was more effective in improving students' mathematical communication skills than students who received ordinary learning, and (3) the interaction between project-based learning models and early mathematical abilities on students' mathematical representation and communication skills. The results showed that the project-based learning model was effectively used in school learning to achieve competency targets and innovative learning.
\end{abstract}

Keywords: 
Communication; Learning; Mathematical; Project; Representation.

\section{PENDAHULUAN}

Pembelajaran merupakan proses yang memiliki nilai tinggi dalam suatu pendidikan disekolah. Proses belajar dalam pembelajaran akan dikelola guru untuk memberikan pengembangan kreatifitas dalam berpikir yang akan dapat meningkatkan kemampuan berpikir serta kemampuan mengkontruksi pengetahuan yang baru. Menurut Dimyati dan Mudjiono (2015), pembelajaran adalah kegiatan yang dilakukan guru dalam desain instruksional secara terprogram, dengan tujuan agar siswa belajar aktif, dan menekankan tersedianya sumber belajar. Ruang kelas adalah salah satu tempat untuk terjadinya proses pembelajaran tersebut. Kelas merupakan kumpulan kelompok siswa dalam suatu waktu yang sama dengan menerima pelajaran dari guru secara bersamaan dan kelas merupakan unit kecil siswa yang melakukan interaksi dengan guru dalam suatu proses pembelajaran dengan memiliki keunikan yang beragam (Arikunto, 2014).

Representasi dalam belajar matematika adalah salah satu dasar pondasi seorang siswa untuk dapat memahami dan menggunakan ide matematika (Amaliyah, 2018). Siswa harus memformulasi suatu masalah matematika menjadi bentuk yang abstrak atau model matematika. Siswa harus punya kemampuan representasi ganda (multiple representation) untuk dapat mengartikulasikan masalah yang sama kedalam bentuk dan pandangan yang berbeda (Dahlan \& Juandi, 2011).

Menurut Ruseffendi (dalam Ansari, 2012) siswa disekolah mempelajari bagian terbesar dari matematika bukan diperoleh dari eksplorasi matematik, tapi dari cara pemberitahuan. Kemampuan siswa dalam menyampaikan ide matematika baik secara lisan maupun tulisan disebut kemampuan komunikasi matematis. Kemampuan ini dapat dikembangkan melalui proses pembelajaran disekolah, salah satunya melalui proses pembelajaran matematika (Hodiyanto, 2017).

Ketercapaian nilai maksimum hasil dan prestasi belajar siswa seolah ditentukan oleh model pembelajaran yang digunakan. Pemilihan model pembelajaran yang tepat yang disesuaikan dengan capaian yang diharapan akan mencapai hasil dan ketuntasan yang maksimal. Beragam capaian yang harus dicapai seorang pendidik terhadap peserta didiknya, dalam hal ini fokus penelitian adalah pada aspek kemampuan representasi dan komunikasi matematis siswa. Hal ini didasari oleh fakta yang telah ditemukan dari hasil observasi awal pada sekolah SD Negeri 118296 Beringin Jaya Pinang Damai bahwa kemampuan representasi matematis yang dimiliki siswa kelas VI masih rendah, dibuktikan dari soal tes awal yang diberikan yang disusun berdasarkan indikator kemampuan representasi dari 35 orang siswa ada lima siswa (14,28\%) yang kategori sudah mampu menyelesaikan soal tes dengan benar (80\%) dan menunjukkan indikator representasi dengan baik, kemudian tiga puluh orang siswa $(85,72 \%)$ belum mampu menyelesaikan soal dengan benar (20\%) dan belum bisa merepresentasikan sesuai indikator dengan baik. Kemudian soal tes awal yang diberikan yang disusun berdasarkan indikator kemampuan komunikasi matematis dari 35 orang siswa ada empat orang siswa $(11,42 \%)$ yang sudah mampu menyelesaikan dengan baik sesuai indikator komunikasi matematis, dan tiga puluh satu orang siswa $(88,57 \%)$ belum mampu menunjukkan capaian indikator dalam menyelesaikan soal dengan baik. Selain hal tersebut diatas, rendahnya tingkat kemampuan representasi dan komunikasi matematis yang dimiliki siswa kelas IV di SD tersebut dilihat dari saat kegiatan proses pembelajaran dikelas, menurut penjelasan 
guru bahwa siswa kelas VI tersebut tidak maksimal dalam pencapaian indikator kemampuan matematis tersebut, ini membuat siswa tidak maksimal dalam pencapaian hasil belajar matematika.

Hubungan kemampuan awal matematik siswa juga tidak terlepas dari hal ini. Dimana tingkat kemampuan awal matematik setiap siswa memiliki perbedaan, tingkat kemampuan awal matematik yang tinggi, sedang dan rendah. Kemampuan awal matematik siswa bukan sepenuhnya menjadi faktor yang menjadi penghambat untuk tetap meningkatkan kemampuan-kemampuan matematis lainnya.

Mengatasi kondisi tersebut, harus mengupayakan model pembelajaran yang dinilai efektif untuk ketercapaian semua aspek-aspek yang diharapkan tersebut dapat maksimal. Model pembelajaran yang diharapkan dapat diterapkan untuk tercapainya aspek kemampuan representasi dan komunikasi matematis adalah model pembelajaran berbasis proyek. Model pembelajaran berbasis proyek melibatkan langsung peserta didik dalam memecahkan masalah yang diberikan atau ditemukan, membuat peserta didik aktif membangun dan mengatur proses pembelajaran, dan juga menjadikan peserta didik yang berpikir realistis. Pembelajaran berbasis proyek merupakan suatu pembelajaran dengan teknik instruksional dalam bentuk tugas-tugas yang bermakna dalam bentuk masalah, yang fungsinya sebagai konteks dan stimulus dalam membe ntuk pengetahuan yang baru dan kemampuan berpikir kritis yang tinggi. Siswa bekerja tim dalam menetapkan tujuan, mendapatkan informasi, dan membuat atau menentukan keputusan (Tiantong, 2013).

Pertimbangan model pembelajaran berbasis proyek juga dilihat dari beberapa penelitian terdahulu, seperti penelitian Maudi (2016), menjelaskan bahwa model pembelajaran berbasis proyek adalah suatu pembelajaran dengan cara memberdayakan siswa dalam mendapatkan pengetahuan dan membentuk pemahaman baru sesuai pengalamannya dengan kemampuan mempresentasikan dengan berbagai bentuk juga membantu terjadi interaksi antar anggota sekelompoknya Sesuai teori kontruktivisme, yang mengemukakan bahwa guru tidak hanya memberikan pengetahuan kepada siswa saja, namun siswa juga harus membangun pengetahuannya sendiri. Berdasarkan kelebihan-kelebihan hal tersebut, peneliti memilih dan menggunakan model ini sebagai solusi untuk meningkatkan kemampuan komunikasi dan representasi matematis siswa pada kelas VI SD Negeri 118296 Beringin Jaya Pinang Damai.

\section{METODE PENELITIAN}

Jenis penelitian ini berbentuk eksperimen semu (quasi eksperimen). Sampel penelitian adalah siswa kelas VI SD Negeri 118296 Tahun 2020 yang terdiri dari 2 kelas dengan jumlah siswa masingmasing 35 dan 35 orang. Sampel penelitian dipilih secara acak (cluster random sampling) untuk ditetapkan menjadi kelompok eksperimen dengan menggunakan model pembelajaran berbasis proyek dan kelompok kontrol dengan pembelajaran biasa.

Desain Penelitian adalah kelompok kontrol pretes-postes. Tujuannya untuk mengetahui peningkatan kemampuan representasi dan kemampuan komunikasi matematis siswa antara kelompok siswa yang memperoleh pembelajaran dengan model pembelajaran berbasis proyek dengan kelompok siswa yang memperoleh pembelajaran biasa. Permasalahan yang diangkat dalam penelitian ini yang menjadi variable adalah kemampuan representasi matematis dan kemampuan komunikasi matematis yang rendah.

Metode pengumpulan data dalam penelitian ini menggunakan metode dokumentasi dan tes. Perangkat tes diuji 
dan dianalisis terlebih dahulu untuk melihat kualitas tesnya yaitu dengan menguji taraf kesukaran, daya beda, reliabilitas dan validitas soal tes.

Metode analisis data hasil penelitian dilakukan dengan dua tahap, yaitu diawali dengan analisis data awal yang merupakan tahapan pemadanan sampel kemudian tahapan analisis data akhir untuk menganalisis dan membuktikan hipotesis penelitian.

Teknik analisis data menggunakan uji $\mathrm{N}$-gain score, uji-t (Tes-t) dan anava dua jalur untuk melihat peningkatan kemampuan representasi dan kemampuan komunikasi matematis siswa dari dua kelas eksperimen dan kontrol. Dan analisis anava dua jalur digunakan untuk mengetahui apakah terdapat interaksi antara model pembelajaran yang diberikan dengan kemampuan awal matematik terhadap peningkatan kemampuan representasi dan komunikasi matematis siswa.

\section{HASIL DAN PEMBAHASAN}

Hasil penelitian adalah kumpulan data yang dikumpulkan melalui teknik pemberian soal tes saat proses pembelajaran sudah selesai dilakukan. Data disusun berdasarkan variabel data yaitu dari masing-masing data kemampuan representasi dan data komunikasi matematis siswa kelas VI dari dua kelompok kelas yang dijadikan acuan yaitu eksperimen dan kontrol. Kemudian data tersebut dianalisis berdasarkan tujuan yang ingin diperoleh. Berikut adalah hasil analisis data yang telah dilakukan:

Tabel 1. Rata-Rata Nilai Gain Kemampuan Representasi Matematis Berdasarkan Kemampuan Awal Matematik Siswa

\begin{tabular}{|c|c|c|c|}
\hline \multirow[b]{2}{*}{ Kelas } & \multirow{2}{*}{$\begin{array}{c}\text { Kemampuan } \\
\text { Matematis } \\
\text { Siswa }\end{array}$} & \multicolumn{2}{|c|}{ Kemampuan Representasi Matematis } \\
\hline & & $\bar{X}$ & SD \\
\hline \multirow{4}{*}{ Eksperimen } & Tinggi (6) & 0,61488 & 0,18950 \\
\hline & Sedang (24) & 0,42829 & 0,19189 \\
\hline & Rendah (5) & 0,25100 & 0,16614 \\
\hline & Total (35) & 0,43496 & 0,21389 \\
\hline \multirow{4}{*}{ Kontrol } & Tinggi (4) & 0,43125 & 0,20364 \\
\hline & Sedang (24) & 0,20050 & 0,15862 \\
\hline & Rendah (7) & 0,04480 & 0,14913 \\
\hline & Total (35) & 0,22552 & 0,17047 \\
\hline
\end{tabular}

Catatan: Skor maksimum setiap butir tes kemampuan representasi matematis 20

$\begin{array}{lll}\begin{array}{l}\text { Berdasarkan tabel } 1 \text { tersebut } \\ \text { ditunjukkan bahwa peningkatan }\end{array} & \begin{array}{l}\text { sedang dari } 24 \text { orang mendapatkan nilai } \\ \text { rata-rata 0,42829 dan standar deviasinya }\end{array} \\ \text { kemampuan representasi matematis } & 0,19189 \text {, sedangkan kelas kontrol dari } \\ \text { siswa dengan menggunakan model } & 24 \text { orang mendapatkan nilai rata-rata } \\ \text { pembelajaran berbasis proyek pada } & 0,20050 \text { dan standar deviasinya } \\ \text { kelompok dengan kemampuan awal } & 0,15862, \text { kemudian pada kelompok } \\ \text { matematik tinggi dari } 6 \text { orang } & \begin{array}{l}\text { dengan kemampuan awal matematik } \\ \text { mendapatkan nilai rata-rata 0,61488 dan }\end{array} \text { rendah dari } 5 \text { orang mendapatkan nilai } \\ \text { standar deviasinya 0,18950, sedangkan } & \text { rata-rata 0,25100 dan standar deviasinya } \\ \text { kelas kontrol dari } 4 \text { orang mendapatkan } & 0,16614 \text {, sedangkan kelas kontrol dari } \\ \text { nilai rata-rata 0,43125 dan standar } & 7 \text { orang mendapatkan nilai rata-rata } \\ \text { deviasinya 0,20364, dan pada kelompok } & 0,04480 \text { dan standar deviasinya } \\ \text { dengan kemampuan awal matematik } & 0,14913 .\end{array}$


Tabel 2. Hasil Uji t Kemampuan Representasi Matematis Siswa

Independent Samples Test

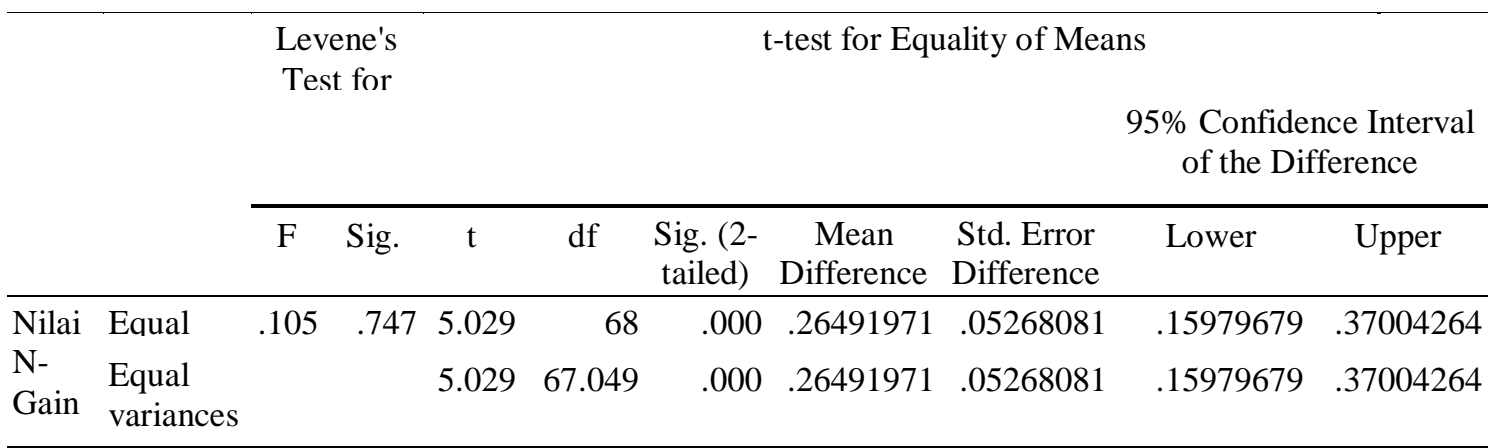

Sumber: Output spss

Berdasarkan tabel 2 diatas, hasil analisis uji-t dengan taraf signifikansi $\alpha=0,05$, maka diperoleh $t_{\text {hitung }}=5,029$ dengan signifikansi 0,000 sedangkan $t_{\text {tabel }}=$ 1,67. Hasil uji $t_{\text {hitung }}>t_{\text {tabel }}(5,029>$ 1,67) dengan kesignifikanan $<0,05$ $(0,000<0,05)$, maka diambil keputusan penolakan $\mathrm{H}_{0}$. Berdasarkan penolakan Ho tersebut diambil kesimpulan bahwa tingkat efektifitas penerapan model pembelajaran berbasis proyek lebih tinggi pada peningkatan kemampuan representasi matematis siswa daripada pada pembelajaran biasa.

Tabel 3. Hasil Uji Anava Berdasarkan Pembelajaran dan Kategori KAM

\begin{tabular}{lrrrrr}
\hline \multicolumn{7}{c}{ Tests of Between-Subjects Effects } \\
\hline Dependent Variable: Nilai N-Gain & \multicolumn{7}{c}{} \\
\hline Source & Type III Sum of & df & Mean Square & F & Sig. \\
Corrected Model & $2.138^{\mathrm{a}}$ & 5 & .428 & 11.063 & .000 \\
Intercept & 4.198 & 1 & 4.198 & 108.632 & .000 \\
Pembelajaran & .593 & 1 & .593 & 15.354 & .000 \\
KAM & .936 & 2 & .468 & 12.107 & .000 \\
Pembelajaran * KAM & .018 & 2 & .009 & .229 & .796 \\
Error & 2.473 & 64 & .039 & & \\
Total & 11.182 & 70 & & & \\
Corrected Total & 4.611 & 69 & & & \\
\hline
\end{tabular}

a. R Squared $=.464$ (Adjusted R Squared $=.422$ )

Sumber : output spss

Berdasarkan Tabel 3 diatas, terlihat bahwa untuk kategori pembelajaran dan kategori KAM (Kemampuan Awal Matematik), nilai signifikansinya $=0,796$. Karena tingkat nilai signifikansi $(0,796)$ ditemukan lebih besar daripada taraf signifikan yang ditentukan yaitu 0,05, maka Ho diterima, yang berarti tidak terdapat interaksi antara pembelajaran dengan kemampuan awal matematik yang dimiliki siswa (kategori tinggi, sedang, rendah) terhadap peningkatan kemampuan representasi matematis siswa. Jadi, peningkatan kemampuan representasi matematis siswa disebabkan oleh perbedaan pembelajaran yang digunakan bukan karena kemampuan awal matematik siswa yaitu tidak terdapat pengaruh secara bersama yang diberikan oleh pembelajaran dan KAM. 
Tabel 4. Rata-Rata Nilai Gain Kemampuan Komunikasi Matematis Berdasarkan Kemampuan Awal Matematik Siswa

\begin{tabular}{|c|c|c|c|}
\hline \multirow[b]{2}{*}{ Kelas } & \multirow{2}{*}{$\begin{array}{c}\text { Kemampuan } \\
\text { Awal } \\
\text { Matematik }\end{array}$} & \multicolumn{2}{|c|}{ Kemampuan Komunikasi Matematis } \\
\hline & & $\bar{X}$ & SD \\
\hline \multirow{4}{*}{ Eksperimen } & Tinggi (6) & 0,71253 & 0,10761 \\
\hline & Sedang (24) & 0,66747 & 0,29801 \\
\hline & Rendah (5) & 0,62874 & 0,05608 \\
\hline & Total (35) & 0,66960 & 0,15390 \\
\hline \multirow{4}{*}{ Kontrol } & Tinggi (4) & 0,26345 & 0,15179 \\
\hline & Sedang (24) & 0,16883 & 0,12679 \\
\hline & Rendah (7) & 0,13377 & 0,11933 \\
\hline & Total (35) & 0,18868 & 0,13264 \\
\hline
\end{tabular}

Catatan: Skor maksimum setiap butir tes kemampuan Komunikasi Matematis 20

Berdasarkan Tabel 4 di atas diperoleh dan 0,05608. Sedangkan untuk bahwa peningkatan kemampuan peningkatan kemampuan komunikasi komunikasi matematis siswa dengan matematis dengan menggunakan menggunakan model pembelajaran pembelajaran biasa yaitu kelompok berbasis proyek mempunyai nilai rata- tinggi mempunyai nilai 0,26345 dan rata dan standar deviasi untuk kelompok $\quad 0,15179$, kelompok sedang 0,16883 dan tinggi 0,71253 dan 0,10761 , sedang 0,12679 , kelompok rendah 0,13377 dan 0,66747 dan 0,29801 , rendah $0,62874 \quad 0,11933$

Tabel 5. Hasil Uji t Kemampuan Komunikasi Matematis

\begin{tabular}{|c|c|c|c|c|c|c|c|c|c|c|}
\hline & & $\begin{array}{l}\text { Lev } \\
\text { Tes } \\
\text { Equa } \\
\text { Vari }\end{array}$ & $\begin{array}{l}\text { vene's } \\
\text { st for } \\
\text { ality o } \\
\text { riances }\end{array}$ & & & & t-test for Equ & Iality of Mea & & \\
\hline & & & & & & & & & $\begin{array}{r}\text { 95\% Co } \\
\text { Interva }\end{array}$ & $\begin{array}{l}\text { nfidence } \\
\text { l of the }\end{array}$ \\
\hline & & $\mathrm{F}$ & Sig. & $\mathrm{t}$ & df & $\begin{array}{l}\text { Sig. } \\
(2-\end{array}$ & $\begin{array}{c}\text { Mean } \\
\text { Difference }\end{array}$ & $\begin{array}{l}\text { Std. Error } \\
\text { Difference }\end{array}$ & Lower & Upper \\
\hline N-Gain_ & $\begin{array}{l}\text { Equal } \\
\text { variances }\end{array}$ & .927 & .339 & 14.873 & 68 & .000 & .52560743 & .0353398 & .45508791 & .59612694 \\
\hline $\begin{array}{l}\text { Komunikas } \\
\text { i Matematis }\end{array}$ & $\begin{array}{l}\text { Equal } \\
\text { variances }\end{array}$ & & & 14.873 & 66.224 & .000 & .52560743 & .0353398 & .45505366 & .59616120 \\
\hline
\end{tabular}

Berdasarkan hasil pada Tabel 5 diatas dengan analisis uji-t dengan penentuan taraf signifikansi $\alpha=0,05$ hasil thitung $=14.873$ dan nilai signifikansi $=0,000$ sedangkan nilai $t_{\text {tabel }}=1,67$. Karena $t_{\text {hitung }}>t_{\text {tabel }} \quad(14.873>1,67) \quad$ dan signifikansi $\quad<0,05 \quad(0,000<0,05)$, sehingga keputusan $\mathrm{H}_{0}$ ditolak. Maka, peningkatan kemampuan komunikasi matematis siswa yang memperoleh model pembelajaran berbasis proyek pada kelas eksperimen lebih tinggi daripada pada kelas kontrol yang memperoleh model pembelajaran biasa. 
Tabel 6. Hasil Uji Anava Berdasarkan Pembelajaran dan Kategori KAM

Tests of Between-Subjects Effects

Dependent Variable: N-Gain Kemampuan Komunikasi Matematis Siswa

\begin{tabular}{lrrrrr}
\hline Source & $\begin{array}{c}\text { Type III Sum of } \\
\text { Squares }\end{array}$ & df & Mean Square & F & Sig. \\
\hline Corrected Model & $4.907^{\mathrm{a}}$ & 5 & .981 & 44.416 & .000 \\
Intercept & 8.122 & 1 & 8.122 & 367.608 & .000 \\
Pembelajaran & 2.614 & 1 & 2.614 & 118.315 & .000 \\
KAM & .061 & 2 & .031 & 1.388 & .257 \\
Pembelajaran * KAM & .019 & 2 & .009 & .427 & .655 \\
Error & 1.414 & 64 & .022 & & \\
Total & 19.593 & 70 & & & \\
Corrected Total & 6.321 & 69 & & &
\end{tabular}

a. R Squared $=.776$ (Adjusted R Squared $=.759$ )

b. Computed using alpha $=.05$

Sumber: Output spss

Dari Tabel 6 terlihat bahwa pada kategori pembelajaran dan KAM (Kemampuan Awal Matematik), hasil yang ditemukan pada nilai signifikansi=0,655. Ditemukan nilai signifikansi tersebut 0,655 lebih besar dari nilai taraf signifikan yang ditentukan 0,05, maka keputusan Ho diterima, dan dapat diambil kesimpulan bahwa tidak ada interaksi antara pembelajaran yang digunakan dengan tingkat kemampuan awal matematik yang dimiliki siswa (tinggi, sedang, rendah) terhadap peningkatan kemampuan komunikasi siswa. Jadi, peningkatan kemampuan komunikasi matematis siswa disebabkan oleh perbedaan pembelajaran yang digunakan bukan karena kemampuan awal matematik siswa dan tidak terdapat pengaruh secara bersama yang diberikan oleh pembelajaran dan kemampuan awal matematik.

Dari hasil analisis data hasil penelitian terlihat bahwa peningkatan kemampuan representasi matematis dan kemampuan komunikasi matematis siswa yang diberi model pembelajaran berbasis proyek lebih baik dibandingkan dengan siswa yang diberi pembelajaran biasa. Ini menunjukkan bahwa pembelajaran berbasis proyek memiliki tingkat efektifitas yang tinggi untuk pencapaian aspek kemampuan representasi matematis dan kemampuan komunikasi matematis siswa kelas VI di SD Negeri 118296 Beringin Jaya Pinang Damai.

\section{SIMPULAN DAN SARAN}

Kesimpulan dari hasil penelitian ini adalah bahwa peningkatan kemampuan representasi matematis dan kemampuan komunikasi matematis siswa yang memperoleh pembelajaran melalui model pembelajaran berbasis proyek lebih tinggi daripada siswa yang memperoleh pembelajaran biasa. Dan tidak terdapat interaksi antara pembelajaran dengan kemampuan awal matematik terhadap peningkatan kemampuan representasi matematis dan kemampuan komunikasi matematis siswa. Pembelajaran berbasis proyek memiliki tingkat efektifitas yang tinggi untuk pencapaian aspek kemampuan representasi matematis dan kemampuan komunikasi matematis siswa kelas VI di SD Negeri 118296 Beringin Jaya Pinang Damai. 
Sedangkan saran peneliti untuk pembaca dan para pendidik adalah peneliti menyarankan penggunaan model pembelajaran berbasis proyek untuk meningkatkan kemampuankemampuan matematis lainnya dan mengembangkan pembelajaran yang inovatif lainnya.

\section{DAFTAR PUSTAKA}

Amaliyah, Rezky AR, Nurfadilah Mahmud. (2018). Analisis Kemampuan Representasi Matematis dalam Pemecahan Masalah Geometri Serta FaktorFaktor yang Mempengaruhinya. JRPM Jurnal Review Pembelajaran Matematika, 2018, 3(2), 146-160

Ansari, B. I. (2012). Komunikasi Matematik dan Politik. Banda Aceh: Yayasan Pena.

Arikunto, Suharsimi. (2014). Prosedur Penelitian Suatu Pendekatan Praktik. Jakarta: Rineka Cipta.

Dahlan, J. A., \& Juandi, D. (2011). Analisis Representasi Matematis
Siswa Sekolah Dasar dalam Pemecahan Masalah Matematika. Jurnal Pengajaran MIPA, Volume 16 , Nomor 1 , 128-138

Dimyati dan Mudjiono. (2015). Belajar dan Pembelajaran. Jakarta: Rineka Cipta.

Hodiyanto. (2017). Kemampuan Komunikasi Matematis dalam Pembelajaran Matematika. AdMathEdu. Vol.7 No.1

Maudi, Nadea. (2016). Implementasi Model Project Based Learning Untuk Meningkatkan Kemampuan Komunikasi Matematis Siswa. Jurnal Pendidikan Matematika Indonesia Volume 1 Nomor 1 bulan Maret 2016. Halaman 39-43 Tiantong, M \& Siksen, S. (2013). The Online Project-based Learning Model Based on Student's Multiple Intelligence. International Journal of Humanities and Social Science, 3(7): 204-211 